\title{
RELATIONSHIP BETWEEN HOMOCYSTEINE AND ISCHEMIC STROKE
}

\author{
AMINUR RAHMAN ${ }^{1}$, RATAN DAS GUPTA ${ }^{2}$, FIROZ AHMED QURAISHI ${ }^{3}$, UTTAM KUMAR SAHA ${ }^{4}$, MD. NURUL \\ AMIN MIAH ${ }^{5}$, ZAHED ALI ${ }^{6}$
}

\begin{abstract}
:
Background: Epidemiologic studies have identified hyper-homocysteinemia as a possible risk factor for atherosclerosis. The aim of the study was based on evaluation of relationship between homocysteinemia with ischemic stroke patients.

Methods and materials: It was a prospective observational study conducted in the Department of Neurology, Sir Salimullah Medical College \& Mitford hospital, Dhaka. Thirty six consecutive patients with ischemic stroke were analyzed by serum total homocysteine, total cholesterol, HDLcholesterol, LDL-cholesterol, triglyceride and Equal number of of controls same ages were compared with the case group.

Result: Mean Fasting blood sugar, serum fasting total cholesterol (TC), serum fasting Low density lipoprotein $(L D L)$ were significantly higher in case group $(p=0.001)$. Serum TC and LDL had a positive correlation with serum homocystine a $(p=0.001)$. Serum High density lipoprotein $(H D L)$ had a negative correlation ( $p=0.718$ ) and serum triglyceride (TG) had a negative correlation ( $p=0.182)$. Total plasma fasting homocysteine level in case group was $21.89 \pm 9.38 \mathrm{imol} / \mathrm{l}$ and control group was $12.31 \pm 3.27 \mathrm{imol} / l,(p=0.001)$. Elevated fasting homocystein level was found in $75.0 \%$ of ischemic stroke patient and in $16.67 \%$ of healthy controls $(p=0.001)$. The incidence of hyperhomocysteinemia is higher in ischaemic stroke cases than that in age-sex matched healthy controls. Hyperhomocysteinemia in ischaemic stroke patients has as been determined as vascular risk factor in our study. Significant correlation has been found between homocysteine concentration and ischaemic stroke.
\end{abstract}

Key words: Homocysteine, carotid artery stenosis, ischemic stroke

\section{Introduction:}

Stroke is a worldwide health problem. It is a major cause of morbidity, mortality and disability in developed as well as developing countries. Hyperhomocysteinemia has been associated with premature peripheral vascular, cerebrovascular, and coronary artery disease. Hyperhomocysteinemia, has been identified as being associated with vascular disease, including cerebrovascular disease ${ }^{1,2}$. Many casecontrol and cohort studies have identified a strong, independent and dose-related association between moderately elevated homocysteine and atherosclerotic vascular disease, including stroke $\mathrm{s}^{3,4,5}$.

In this study, we undertook a prospective casecontrol study of consecutive patients hospitalized with a first-ever ischemic stroke and examined specifically whether there may be an association between homocysteine, serum lipid profile and ischemic stroke. The current study was aimed to explore the relationship of serum homocysteine with ischemic stroke.

\section{Methods:}

This prospective, case-control study of serum total homocysteine as a potential risk factor for acute ischemic stroke. 36 consecutive male and female patients admitted in the department of Medicine and Neurology of Sir Salimullah Medical College \& Mitford Hospital (Dhaka, Bangladesh) from January 2008 June 2009 with the diagnosis of acute ischemic stroke was included in this study and they were compared

1. Registrar, Department of Neurology, Sir Salimullah Medical College Mitford Hospital, Dhaka

2. Assistant Professor, Department of Nephrology, Dhaka Medical College, Dhaka

3. Professor, Department of Neurology, National Institute of Neurosciences \& Hospital, Dhaka.

4. Assistant Professor, Department of Neurology, Sir Salimullah Medical College, Dhaka.

.5. Assistant Professor, Department of Medicine, Sir Salimullah Medical College, Dhaka Dhaka

6. Assistant Professor, Department of Neurology, Sir Salimullah Medical College, Dhaka

Address of Correspondence: Dr. Aminur Rahman, Registrar, Department of Neurology, Sir Salimullah Medical College Mitford Hospital, Dhaka.

Bangladesh J Medicine 2014; 25 : 8-12 
BJM Vol. 25 No. 1

with 36 control age-matched volunteer subjects of outpatient department. Criteria for entry into the study were follows: (1) with neurological examination and neuroimaging (CT/ MRI) methods, diagnosis of ischemic stroke was strictly verified within 48 hours, (2) no disorders related to hepatic, renal and endocrinologic functions, (3) no systemic malignancy, (4) The subjects that do not use any preparations including vitamin B12 and folic acid or any medications having antimetabolite effects such as methotrexate or phenytoin, etc.

Stroke was defined as a clinical syndrome characterized by rapidly developing clinical symptoms and/or signs focal and at times global loss of brain function, with symptoms lasting $>24$ hours or leading to earlier death, and with no apparent cause other than that of vascular origin ${ }^{6}$.

All patients were examined by a neurologist and they had Cranial Tomography (CT) or Magnetic Resonance Imaging (MRI). Clinical information including age, sex, history or current evidence of Hypertension (HT) [systolic blood pressure (SBP)e"150mmHg and diastolic BP e"90mmHg], Diabetes Mellitus (DM) [fasting blood glucose 3.5-5.5 mmol/L], cardiac disease, were recorded for all subjects. In case, venous blood samples were obtained after their admission and in control subjects from outpatient department in the morning after an overnight fast of at least 12 hours into EDTA tubes. Serum total cholesterol, HDL cholesterol (HDL-C), LDL cholesterol (LDL-C), VLDL cholesterol (VLDL-C) and triglycerides were measured by using standard enzymatic procedures. Borderline for normal values were total cholesterol $<5.2 \mathrm{mmol} / \mathrm{L}$, HDL-C $>1.0$ $\mathrm{mmol} / \mathrm{L}, \mathrm{LDL}-\mathrm{C}<3.0 \mathrm{mmol} / \mathrm{L}, \mathrm{VLDL}<1.1 \mathrm{mmol} / \mathrm{L}$ and triglyceride $<2.3 \mathrm{mmol} / \mathrm{L}$. Total plasma homocysteine level was measured in subjects within the first 48 hours after stroke onset. Plasma homocysteine levels were determined with FPIA (fluorescence polarization immunoassay) on the Abbott AxSYM system. Kit supplied from AxSYM Germany. The upper limit of the manufacturer and the laboratory was $15 \mathrm{mmol} / \mathrm{L}$. Values above $15 \mathrm{mmol} /$ L were acceptably high.

Statistical analyses related with this study were performed by use of SPSS 13 package program. In the course of the evaluation of the data gathered, descriptive statistical methods (average, standard deviation) were used; in addition to these methods, free $t$ test was used for the comparison between the paired groups through the use of the non-parametric tests taking into consideration the number of patients in the groups composed with the classification of the patient group by etiologies. The comparisons between the groups were evaluated with the chi-square test was used for the comparisons between the qualitative data. Correlations between
Relationship Between Homocysteine and Ischemic Stroke

numeric variables, like cholesterol, triglyceride and homocysteine were investigated by t test. The results of these tests were considered at the significance level of $\mathrm{p}<0.05$ and the confidence interval $95 \%$.

\section{Results and observations}

36 patients with ischemic stroke (18 female and 18 male) and 36 control subjects ( 18 male and 18 female) were included in the study. The mean age of the patient group was within the range of $50.28 \pm 14.29$ and the mean age of the control group was within the range of $51.08 \pm 14.50$ (Table 1$)$

Table-I

Distribution of age by group

\begin{tabular}{lccc}
\hline Age (in year) & \multicolumn{2}{c}{ Group } & p value* \\
& Case & Control & \\
\hline$\leq 30$ & $3(8.3) \#$ & $4(11.1)$ & \\
$30-50$ & $17(47.2)$ & $15(41.7)$ & \\
$50-70$ & $14(38.9)$ & $15(41.7)$ & \\
$>70$ & $2(5.6)$ & $2(5.6)$ & \\
\hline Total & $36(100.0)$ & $36(100.0)$ & \\
\hline Mean \pm SD & $50.28 \pm 14.29$ & $51.08 \pm 14.50$ & 0.813 \\
\hline
\end{tabular}

*t test was done to measure the level of significance.

\#Figure within parentheses indicates in percentage.

In respect of the risk factors, HT, Ischemic Heart Disease (IHD), DM displayed significantly higher rates of prevalence in the patient population. In the patient group, only HT was found to be significantly higher in Case group in respect of the distribution of the risk factors in the etiological subgroups $(p=0.0 .230)$; any significant difference has not been determined.(Table-II)

Table-II

Distribution of history of risk factors by group

\begin{tabular}{lccc}
\hline Risk factors & \multicolumn{2}{c}{ Group } & $p$ \\
& Case & Control & value* \\
\hline Hypertension(HT) & $17(47.2) \#$ & $12(33.3)$ & 0.230 \\
Ischemic heart & $7(19.4) \#$ & $6(16.7)$ & 0.759 \\
disease(IHD) & & & \\
Valvular heart disease & $2(5.6) \#$ & $0(0.0)$ & 0.151 \\
Diabetes mellitus(DM) & $9(25.7) \#$ & $8(22.9)$ & 0.780 \\
\hline
\end{tabular}

${ }^{*}$ Chi square test was done to measure the level of significance. \#Figure within parentheses indicates in percentage.

Mean, standard deviation of fasting total cholesterol, triglyceride, HDL-C, LDL-C and VLDL$\mathrm{C}$ in patients and control group summarized in Table 3. There was no statistical difference between the two groups. 
Table-III

Fasting blood sugar, serum fasting lipid profile and fasting total plasma homocysteine level by group

\begin{tabular}{|c|c|c|c|}
\hline \multirow[t]{2}{*}{ Parameter } & \multicolumn{2}{|c|}{ Group } & \multirow[t]{2}{*}{ P value* } \\
\hline & $\operatorname{Case}(n=36)$ & Control( $(n=36)$ & \\
\hline Fasting blood sugar $(\mathrm{mmol} / \mathrm{l})$ & $8.30 \pm 3.82$ & $5.87 \pm 1.77$ & 0.001 \\
\hline Total Cholesterol (TC) (mg/dl) & $207.14 \pm 56.52$ & $166.69 \pm 28.55$ & 0.001 \\
\hline HDL (mg/dl) & $35.94 \pm 15.95$ & $39.14 \pm 18.27$ & 0.432 \\
\hline $\mathrm{LDL}(\mathrm{mg} / \mathrm{dl})$ & $137.06 \pm 57.21$ & $93.13 \pm 26.44$ & 0.001 \\
\hline Triglyceride (TG) (mg/dl) & $205.19 \pm 77.03$ & $183.19 \pm 60.60$ & 0.182 \\
\hline Total plasma homocysteine level(fasting) (mmol/1) & $21.89 \pm 9.38$ & $12.31 \pm 3.27$ & 0.001 \\
\hline
\end{tabular}

*t test was done to measure the level of significance.

\#Figure within parentheses indicates in percentage.

Compared to the control subjects, the mean fasting plasma homocysteine level was found to be significantly higher $(p<0,01)$. While the homocysteine concentration was found within the normal levels in $25 \%$ of the patients, it was found to be elevated in $75 \%$. The homocysteine level in the control group was found to be within normal levels for $83.33 \%$ of the control subjects; and only $16.67 \%$ of the control subjects displayed elevated levels of homocysteine. (Table-IV)

Table-IV

Distribution of respondents according to level of homocysteine by group

\begin{tabular}{lcccc}
\hline \multirow{2}{*}{ Homocysteine } & \multicolumn{2}{c}{ Group } & Total & p value* \\
& Case (\%) & Control (\%) & & \\
\hline Normal & $9(25.0) \#$ & $30(83.33)$ & $46(63.89)$ & 0.0 .001 \\
Elevated & $27(75.0)$ & $6(16.67)$ & $26(36.11)$ & \\
\hline Total & $36(100.0)$ & 36 & $(100.0)$ & $72(100.00)$ \\
\hline
\end{tabular}

${ }^{*}$ Chi square test was done to measure the level of significance. \#Figure within parentheses indicates in percentage.

In the determination of correlation between the homocysteine level and lipid levels in the patient group Serum TC and LDL had a positive correlation with serum homocystine with a $\mathrm{p}$ value 0.001 . Serum HDL had a negative correlation with $\mathrm{p}$ value 0.718 and TG had a positive with a p value 0.205. (Table 5)

Table-V

Correlation between serum fasting lipid profiles with total plasma homocysteine level

\begin{tabular}{lcc}
\hline Serum fasting lipid profiles & r value & p value \\
\hline TC(mg/dl) & 0.388 & 0.001 \\
HDL(mg/dl) & -0.043 & 0.718 \\
LDL(mg/dl) & 0.416 & 0.001 \\
TG(mg/dl) & 0.151 & 0.205 \\
\hline
\end{tabular}

Pearson's correlation was done to find the significance value. Pearson's correlation, $\mathrm{r}=0.151, \mathrm{p}=0.205$

\section{Discussion:}

In this study, we have aimed to determine the correlation between the plasma homocysteine level and stroke and to discover the association between the elevated plasma levels and the lipid levels and ischemic stroke. Elevated plasma total homocysteine (tHcy) levels have been indicated as a risk factor for coronary heart disease $8,9,10$, ischemic stroke ${ }^{11,12}$, and peripheral artery disease ${ }^{13,14}$. However, most of these findings were derived from white populations, and whether such findings also apply for Asians remains to be determined. Mean age of the cases were $50.28 \pm 14.29$ years and controls were $51.08 \pm$ 14.50 years, with no significant difference between two groups. Most of the subjects were from age group between above twenty to eighty years. In previous same type of study to explore the association of homocysteine with ischemic stroke the mean age was 66 years $^{15}$, and in other study it was $66.2 \pm 11.0$ years ${ }^{16}$. Diabetes mellitus, hypertension and ischemic heart disease, family history of hypertension and diabetes mellitus, smoking are considered as significant risk factors of stroke. In some of the studies that are limited in number, any association with known risk factors has not been determined ${ }^{17}$. In numerous studies, elevated homocysteine levels were found to be significantly correlated and associated with smoking, male gender, hyperlipidemia and hypertension 18.19 .

In present study mean serum fasting sugar, serum fasting lipid profile (TC) and serum LDL was significantly higher among cases, but serum HDL and triglyceride (TG) had no such difference. In a series mean ( \pm standard deviation) of total cholesterol, triglyceride, HDL-C, LDL-C and VLDL-C in patients and control group summarized had no statistical difference ${ }^{20}$.

Hyperhomocystenaemia defined an elevated homocysteine concentration as one that exceeds 15.8 
BJM Vol. 25 No. 1

mmol per liter (95th percentile for healthy control subjects) ${ }^{21}$. Other defined an elevated homocysteine concentration as one that exceeded $13.9 \mathrm{mmol}$ per liter (the mean value plus 2 SD among healthy young controls) ${ }^{22}$. In the Framingham Heart Study cohort had previously considered a homocysteine concentration of $14 \mathrm{mmol}$ per liter to be elevated (90th percentile for persons with apparently adequate concentrations of folate, vitamin B12, and vitamin B6) ${ }^{23}$. In current study, serum fasting total plasma homocysteine level in case group was $21.89 \pm 9.38$ imol/1 which was significantly higher than the controls $(12.31 \pm 3.27 \mathrm{imol} / 1),(\mathrm{p}=0.001)$.

In a series the median concentration of total homocysteine was $16.4 \mathrm{mmol} / \mathrm{L}$ among cases versus $14.3 \mathrm{mmol} / \mathrm{L}$ among controls ${ }^{24}$. Concentrations of total homocysteine were higher in two thirds of the matched pairs in the case subjects ${ }^{25}$.

In current study $25.0 \%$ of cases serum total homocysteine level was normal and in $75.0 \%$ of cases it was elevated. In control group in $83.33 \%$ respondents it was within normal level and $16.67 \%$ elevated. Homocysteine level was significantly higher among cases $(p=0.001)$. In a recent study the homocysteine concentration was found within the normal levels in $35.4 \%$ of the patients, it was found to be lightly elevated in $56.3 \%$ of the patients and moderately elevated in $8.3 \%$. The homocysteine level in the control group was found to be within normal levels for $90 \%$ of the control subjects; and only $10 \%$ of the control subjects displayed lightly elevated levels of homocysteine $(p<0.01)^{21}$. In a study, total homocysteine level was normal in $71.5 \%$ of stroke cases and elevated in $28.5 \% 26$. Serum total cholesterol (TC), LDL had a positive correlation with serum homocysteine with a $\mathrm{p}$ value 0.001 . Serum HDL had a negative correlation and TG had a positive with no statistical significance.

Fujishama reported that as a manifestation lacunar infarction is the most prevalent type of ischemic stroke in relation to elevated homocysteine Japanese people 27 . Another studies carried out in relation with etiological correlations, Eikelboom and colleagues have found in a case-control study that hyperhomocysteinemia is associated in particular with stroke due to atherosclerosis.

Although Mousavi et al, failed to demonstrate any meaningful difference in homocysteine related atherosclerosis in the Asian population 28.

The current study demonstrated that higher level of homocysteine is significantly associated with ischemic stroke and hyperhomocysteinemia is an independent risk factor of ischemic stroke.
Relationship Between Homocysteine and Ischemic Stroke

\section{References:}

1. Clarke R, Daly L, Robinson $\mathrm{K}$, et al. Hyperhomocysteinemia: an independent risk factor for vascular disease. NEngl J Med 1991; 324: 114955

2. Sacco RL. Newer risk factors for stroke. Neurology 2001; 57: 831-834

3. Jacobsen DW, Gatautis VJ, Green R, et al. Rapid HPLC Determination of Total Homocysteine and Other Thiols in Serum and Plasma: Sex Differences and Correlation with Cobalamin and Folate Concentrations in Healthy Subjects. Clin Chem 1994; 40: 873-881

4. Kang SS, Wong PW, Malinow MR. Hyperhomocyst(e)inemia as a risk factor for occlusive vascular disease. Ann Rev Nutr 1992; 12: 279-98

5. Korezyn AD. Homocysteine, stroke, and dementia. Stroke 2002; 33: 2343-2344

6. Hatano S. Experience from a multicentre stroke register: a preliminary report. Bull World Health Organ. 1976;54: 541-553

7. Warlow CP, Dennis MS, van Gijn J, Hankey GJ, Sandercock PAG, Bamford JM. Stroke: A Practical Guide to Management. Oxford, UK: Blackwell Scientific Productions, 1996

8. Stampfer MJ, Malinow MR, Willett WC, et al. A prospective study of plasma homocyst(e)ine and risk of myocardial infarction in US physicians. JAMA 1992; 268: 877-81.

9. Clarke R, Fitzgerald D, O’Brien C, O’Farrell C, Roche G, Parker RA, Graham I., Hyperhomocysteinaemia: a risk factor for extracranial carotid artery atherosclerosis. Irish J Med Sci 1992; 161:61-5.

10. Kang SS, Wong PW, Malinow MR. Hyperhomocystinemia as a risk factor for occlusive vascular disease. Ann Rev Nutr. 1992; 12: 297-98.

11. Verbose P, Hennekens CH, Malinow RM, Kok FJ, Willett WC, Stampfer MJ. A prospective study of plasma homocyst(e)ine and risk for ischemic stroke. Stroke. 1994; 25:1924-1930.

12. Perry IJ, Refsum H, Morris RW, Ebrahim SB, Ueland PM, Shaper AG. Prospective study of serum total homocysteine concentration and risk of stroke in middle-aged British men. Lancet. 1995;346:13951398.

13. Giles WH, Croft JB, Greenlund KJ, Ford ES, Kittner SJ. Total homocysteine concentration and the likelihood of nonfatal stroke: results from the third National Health and Nutrition Examination Survey, 1988-1994.Stroke. 1998; 29:2473-2477.

14. Taylor LM, DeFrang RD, Harris EJ Jr, Porter JM. The association of elevated plasma homocysteine with progression of symptomatic peripheral arterial disease. J Vasc Surg. 1991; 13:128-136

15. Selhub J, Jacques PF, Bostom AG, D'Agostino RB, 
Wilson PWF, Belanger AJ, et al, Association Between Plasma Homocysteine Concentrations And Extracranial Carotid-Artery Stenosis, N Engl J Med 1995;332:286-91.

16. Sasaki T, Watanabe $\mathrm{M}$, Nagai $\mathrm{Y}$; Hoshi $\mathrm{T}$, Takasawa M, Nukata M, Taguchi A, Kitagawa K , Kinoshita N, Matsumoto M. Association of Plasma Homocysteine Concentration with Atherosclerotic Carotid Plaques and Lacunar Infarction, Stroke. 2002; 33:1493-96.

17. Millan-Guerrero RO, Vazquez C, Isais-Aguilar L, Trujillo-Hernandez B. Hyperhomocysteinemia in acute cerebral infarction. Gac Med Mex 2003; 139: 307-10.

18. Mizrahi EH, Noy S, Sela BA, Fleissig Y, Arad M, Adunsky A. Further evidence of interrelation between homocysteine and hypertension in stroke patients:a cross-sectional study.Isr Med Assoc J 2003; 5: 791-4.17

19. Graham IM, Daly LE, Refsum HM, Robinson K, Brattström LE, Ueland PM, Palma-Reis RJ, Boers $\mathrm{GH}$, Plasma Homocysteine as a risk factor for vascular disease. JAMA 1997; 277: 1775-1781.

20. Somay G, Aliskan T, Erenoglu NY. Carotid Artery Stenosis and Homocysteine in Ischemic Stroke: A case-control study. Journal of Neurological Sciences (Turkish) 2005, Volume 22, Number 4, Page(s) 394402 .

21. Stampfer MJ, Malinow MR, Willett WC, et al. A prospective study of plasma homocyst(e)ine and risk of myocardial infarction in US physicians. JAMA 1992; 268: 877-81.

22. Joosten E, van den Berg A, Riezler R, Naurath HJ,
Lindenbaum J, Stabler SP, Allen RH. Metabolic evidence that deficiencies of vitamin B-12 (cobalamin), folate, and vitamin B-6 occur commonly in elderly people. Am J Clin Nutr 1993; 58:468-76

23. Selhub J, Jacques PF, Wilson PWF, Rush D, Rosenberg IH. Vitamin status and intake as primary determinants of homocysteinaemia in an elderly population. JAMA 1993; 270: 2693-98.

24. Sasaki $\mathrm{T}$, Watanabe $\mathrm{M}$, Nagai $\mathrm{Y}$; Hoshi $\mathrm{T}$, Takasawa M, Nukata M, Taguchi A, Kitagawa K , Kinoshita N, Matsumoto M. Association of Plasma Homocysteine Concentration with Atherosclerotic Carotid Plaques and Lacunar Infarction, Stroke. 2002; 33:1493-96.

25. Tanne D, Haim M, Goldbourt U, Boyko V, Doolman $\mathrm{R}$, Adler $\mathrm{Y}$, et al, Prospective Study of Serum Homocysteine and Risk of Ischemic Stroke Among Patients With Preexisting Coronary Heart Disease. Stroke. 2003;34:632-636

26. Mousavi SA, Ghasemi M, Hoseini T. Association between plasma homocysteine concentrations and extracranial carotid stenosis. Ann Saudi Med [serial online] 2006 [cited 2009 Nov 18]; 26:120-2.

27. Fujishima M. Cerebrovascular disorders among Japanese. J Jpn Soc Intern Med. 1996;85:14071418.

28. Mousavi SA, Ghasemi M, Hoseini T. Association between plasma homocysteine concentrations and extracranial carotid stenosis. Ann Saudi Med 26:120-2.norn. 